Economics Development Analysis Journal 7 (2)(2018)

\title{
Analisis Finansial Pertanian Garam dan Pengguna Geoisolator di Kecamatan Batangan dan Juwana
}

\author{
Angga Dwi Prayitno ${ }^{1 凶}$, Prasetyo Ari Wibowo ${ }^{2}$
}

Jurusan Ekonomi Pembangunan, Fakultas Ekonomi, Universitas Negeri Semarang

\begin{tabular}{|c|c|}
\hline Info Artikel & Abstrak \\
\hline $\begin{array}{l}\text { Sejarah Artikel: } \\
\text { Diterima Januari } 2017 \\
\text { Disetujui Maret } 2017 \\
\text { Dipublikasikan Mei } 2017\end{array}$ & $\begin{array}{l}\text { Tujuan dari penelitian ini adalah menganalisis keuntungan serta kelayakan finansial pada usaha } \\
\text { pertanian garam tradisional dan pengguna geoisolator di Kabupaten Pati. Metode penelitian adalah } \\
\text { studi kasus, alat analisis yang digunakan adalah analisis deskriptif, analisis pendapatan usaha tani, } \\
\text { serta analisis kelayakan investasi. Hasil penelitian menunjukkan mekanisme produksi usaha } \\
\text { pertanian garam tradisional dan pengguna geoisolator hampir sama, perbedaannya pada media yang }\end{array}$ \\
\hline $\begin{array}{l}\text { Keywords: } \\
\text { Analisis Finansial, Garam, } \\
\text { Geoisolator, Tradisional }\end{array}$ & $\begin{array}{l}\text { digunakan. Usaha pertanian garam pengguna geoisolator lebih menguntungkan untuk dijalankan } \\
\text { karena keuntungan yang diperoleh lebih besar daripada tradisional. Kelayakan investasi pada usaha } \\
\text { pertanian garam tradisional dan pengguna geoisolator sama-sama layak dilihat dari nilai NPV, Net } \\
\text { B/C, dan IRR. Penurunan harga sangat mempengaruhi keuntungan serta kelayakan usaha pertanian } \\
\text { garam. Usaha pertanian garam pengguna geoisolator lebih sensitif dibandingkan tradisional apabila } \\
\text { terjadi penurunan harga sebesar } 24,5 \% \text {.. }\end{array}$ \\
\hline
\end{tabular}

\begin{abstract}
The purpose of this research is to analyze the profit and financial feasibility of traditional salt farming business and geoisolator users in Pati Regency. The research method is a case study, the analytical tool used is descriptive analysis, farm income analysis, and investment feasibility analysis. The results show that the production mechanism of traditional salt farming and geoisolator users is almost the same, the difference is in the media used. Salt farming users of geoisolators are more profitable to run because the profits gained are greater than the traditional ones. The feasibility of investing in traditional salt farming and geoisolator users is equally feasible in terms of NPV, Net B / C, and IRR values. The decrease in prices greatly affect the profits and feasibility of salt farming business. The salt farming business of geoisolator are more sensitive than tradisional in the event of a $24.5 \%$ price reduction.
\end{abstract}

(C) 2018 Universitas Negeri Semarang

${ }^{凶}$ Alamat korespondensi:
Ruang Jurnal Gedung L FE UNNES, Sekaran Gunungpati
Semarang, 50229, Indonesia
E-mail: anggadwipvs@gmail.com

ISSN 2252-6965 


\section{PENDAHULUAN}

Garam menjadi salah satu komoditas strategis nasional yang kedudukannya tidak kalah penting jika dibandingkan dengan kebutuhan pokok lainnya, mengingat peran dan fungsi yang dimilikinya. Selain berfungsi sebagai bahan pangan, garam juga berfungsi sebagai bahan baku bagi industri dalam negeri.

Sebagian besar produksi garam dilakukan secara individual oleh petani garam sehingga produksi garam mempunyai produktivitas yang rendah dan kualitas garam yang relatif rendah pula sehingga tidak memenuhi spesifikasi yang disyaratkan oleh industri di dalam negeri (Efendy, et al., 2016). Apabila dibandingkan antara kebutuhan nasional dan kemampuan produksi, maka produksi garam nasional hanya mampu memenuhi kebutuhan dari sisi konsumsi saja, sementara untuk kebutuhan bahan baku industri masih bergantung pada impor.

Sentra produksi garam di Indonesia tersebar luas hingga 48 wilayah termasuk Provinsi Jawa Tengah. Menurut Dinas Kelautan dan Perikanan Provinsi Jawa Tengah, pada tahun 2015 produksi garam Jawa Tengah mencapai 841.543 ton sekaligus menjadi penyumbang $30 \%$ kebutuhan garam nasional. Besarnya kontribusi tersebut dikarenakan provinsi Jawa Tengah memiliki sentra produksi garam yang tersebar sepanjang garis pantai utara meliputi wilayah Kabupaten Brebes, Demak, Jepara, Pati, dan Rembang. Tahun 2015 Produksi tertinggi ada di Kabupaten Pati dengan rata-rata produksi menyumbang $45 \%$ dari total produksi garam di Jawa Tengah.

Tingginya produktivitas garam di Kabupaten Pati menunjukkan besarnya potensi yang bisa dikembangkan. Selain itu, produksi garam juga sebagai salah satu sumber mata pencaharian utama masyarakat desa di Kabupaten Pati, sehingga diharapkan garam dapat meningkatkan kesejahteraan para pelakunya. Namun pada kenyataannya, usaha garam belum mampu memberikan keuntungan lebih bagi petani garam. Hasil observasi awal menunjukkan bahwa pendapatan petani garam masih relatif rendah, hal tersebut terjadi karena masa produksi garam hanya bisa dilakukan pada musim kemarau, selain itu disebabkan pula karena nilai jual garam yang rendah.

Harga jual garam lokal yang rendah dikarenakan masih rendahnya kualitas garam yang dihasilkan. Hal serupa juga pernah diungkapkan oleh Haryanto dalam Pranowo dan Muhajir (2015) dimana kondisi di lapangan tahun 2013 menujukan bahwa harga garam per kilogram di tingkat petani masih dibawah $\mathrm{Rp}$ 550 , penyebabnya adalah kadar $\mathrm{NaCl}$ garam krosok yang dihasilkan petani garam di Kabupaten Pati berkisar 75\%-85\%, sedangkan permintaan garam untuk industri harus memiliki kadar $\mathrm{NaCl}$ minimal $97 \%$ sementara garam konsumsi minimal memiliki kadar $\mathrm{NaCl}$ 94\%.

Total produksi garam di Kabupaten Pati tahun 2015 menghasilkan 381.704 ton yang terdiri dari garam KP 2 dan KP 1. Kecamatan Batangan dan Juwana menjadi produsen terbesar yang menghasilkan 74 persen dari total produksi garam. Gambar 1 menujukan produksi garam berdasarkan kualitas di Kabupaten Pati.

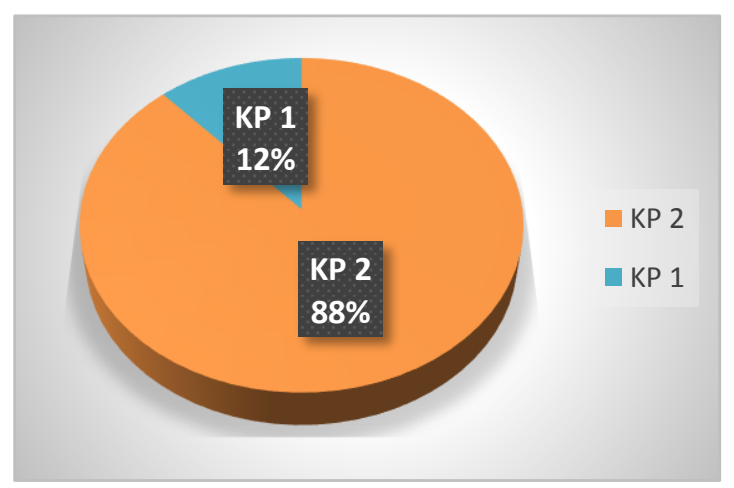

Gambar 1. Produksi Garam di Kabupaten Pati

Tahun 2015

Sumber: Laporan Akhir Pugar 2015

Gambar 1 menunjukkan bahwa garam KP 2 yang berguna untuk garam konsumsi lebih dominan di produksi oleh petani garam. Sementara garam KP 1 yang berguna untuk kebutuhan garam industri hanya mampu di produksi sebanyak $12 \%$ dari total produksi. Hal tersebut menujukkan bahwa produksi garam di Kabupaten Pati secara kuantitas cukup besar, namun secara kualitas masih rendah. 
Berkaitan dengan kondisi tersebut, Dinas Kelautan dan Perikanan Kabupaten Pati melalui Program Pemberdayaan Usaha Garam Rakyat (Pugar) memberikan bantuan untuk menerapkan Teknologi Tepat Guna (TTG) melalui penggunaan geoisolator kepada kelompok petani garam dengan tujuan untuk meningkatkan kualitas serta kuantitas garam yang dihasilkan sehingga harga jual garam meningkat yang selanjutnya diharapkan akan meningkatkan pendapatan petani garam. Penelitian terkait penggunaan geoisolator pernah dilakukan oleh Hidayah (2016) yang menyimpulkan bahwa penggunaan geoisolator bisa meningkatkan produksi garam hingga mencapai $30 \%$ dan menurut Soesilowati (2014) margin pemasaran garam menggunakan media geoisolator meningkat hingga Rp 1.750.000,-/ton untuk KP2 dan Rp 2.150.000,-/ton untuk KP1.

Awal pengenalan penggunaan geoisolator belum dapat di terima sepenuhnya oleh petani garam. Menurut Pranowo dan Muhajir (2015) pelaksanaan Pugar tahun 2014 di Kabupaten Pati tidak berjalan dengan baik, karena adanya penolakan penggunaan geoisolator dalam pembuatan garam oleh para petani. Petani garam di Kabupaten Pati beranggapan bahwa menggunakan geoisolator dapat mengurangi jumlah produksi garam mereka karena masa panen yang lebih lama. Selain itu, petani garam juga menganggap penggunaan geoisolator hanya akan menambah beban biaya produksi karena harga plastik yang dijadikan sebagai media memiliki harga yang mahal serta sulit untuk dilakukan pemeliharaan dan perawatan.

Penggunaan Geoisolator untuk usaha pertanian garam dinilai sangat memuaskan, dengan indikator peningkatan kualitas serta kuantitas garam yang dihasilkan. Indikator tersebut merujuk pada kelayakan teknis penggunaan geoisolator, namun untuk kelayakan finansial penggunaan geoisolator belum dijelaskan. Dengan demikian perlu kajian tentang analisis finansial antara usaha pertanian garam pengguna geoisolator dan tidak menggunakan, sebagai gambaran untuk petani garam.

\section{METODE PENELITIAN}

Metode yang digunakan adalah studi kasus. Sumber data berasal dari data primer yang diperoleh langsung dari lapangan, serta data sekunder yang berasal dari bacaan serta instansi pemerintahan. Metode pengambilan sampel dengan menggunakan purposive sampling dengan kriteria petani garam rakyat yang menggarap lahan seluas satu hektar dan kepemilikannya. Kriteria lain yaitu petani garam tradisional dan penggunaan geoisolator dari tahun 2014.

Bertitik tolak dari kriteria sampling tersebut dan berdasarkan pula pada rekomendasi dari Dinas Kelautan dan Perikanan Kabupaten Pati serta ketua kelompok usaha pertanian garam, penulis memperoleh delapan sampel meliputi empat sampel petani garam tradisional dan empat sampel petani garam pengguna geoisolator. Di ambil delapan sampel dikarenakan output hasil usaha pertanian yang paling mempengaruhi adalah luas lahan, sehingga kalau sudah ditentukan kriteria sampling penelitian satu hektar maka sampel penelitian berapapun hasilnya akan tidak jauh berbeda.

Data yang diperoleh akan dianalisis menggunakan analisis deskriptif serta analisis finansial yang dibagi menjadi tiga indikator yaitu analisis pendapatan usaha tani, analisis kelayakan investasi, analisis sensitivitas. Analisis Deskriptif digunakan sebagai alat untuk mengetahui dan menjelaskan mekanisme produksi usaha pertanian garam yang ada di Kabupaten Pati. Analisis pendapatan usaha pertanian garam meliputi perhitungan terhadap: biaya, penerimaan, keuntungan usaha tani, Revenue-Cost Ratio (R/C Ratio) dan Break Even Point (BEP) (Amaliya, 2007). Analisis Pendapatan usaha tani digunakan untuk mengetahui besarnya input dan output produksi garam serta pendapatan yang diperoleh petani garam. Komponen biaya terdiri dari biaya variable, biaya tetap dan biaya investasi (Soekartawi, 2002). Komponen penerimaan berupa penghasilan yang diterima oleh petani garam dari hasil penjualan produknya. 
Pendapatan usaha merupakan selisih total penerimaan dikurangi total biaya (Soeharjo dan Patong, 1973). Analisis R/C bertujuan untuk melihat seberapa jauh setiap nilai rupiah biaya yang dikeluarkan dalam kegiatan usaha garam dapat memberikan sejumlah nilai penerimaan sebagai manfaatnya. Break even point (BEP) digunakan untuk melihat batas minimal produk yang harus diproduksi agar suatu usaha dapat memberikan keuntungan (Ibrahim, 2009).

Analisis Kelayakan finansial dilakukan untuk mengetahui layak tidaknya usaha tersebut dikembangkan dari aspek finansial atau keuangan. Adapun indikator untuk mengetahui proyek atau usah tersebut layak tidaknya dapat melalui perhitungan meliputi: Net Present Value (NPV), Net Benefit Cost Ratio (Net B/C Ratio), dan Internal Rate of Retrun (IRR) (Pasaribu, 2012). Net Present Value (NPV) merupakan nilai sekarang (Present Value) dari selisih antara benefit (manfaat) dengan cost (biaya) pada discount rate tertentu. Net Benefit Cost Ratio adalah perbandingan antara jumlah NPV positif dengan jumlah NPV negatif. IRR ialah untuk mengetahui sebagai alat ukur kemampuan proyek dalam mengembalikan bunga pinjaman dari lembaga internal keuangan yang membiayai proyek/usaha terebut. Proyek atau usaha dikatakan layak jika NPV $>0$, Net $B / C>1$, dan IRR $>$ discount rate (Pasaribu, 2012). Variabel harga yang seringkali berubah-ubah setiap saat membuat analisis kelayakan finansial akan berubah-ubah (Sinaga 2009). Sehingga diperlukan analisis sensitivitas untuk melihat kepekaan usaha pertanian garam apabila terjadi perubahan-perubahan terhadap harga jual..

\section{HASIL DAN PEMBAHASAN}

kegiatan usaha pertanian garam di kecamatan batangan dan juwana kabupaten pati, kegiatan produksi usaha pertanian garam yang ada di kecamatan Batangan dan Juwana Kabupaten Pati terdapat dua sistem pembuatan garam rakyat, yaitu penggaraman dengan sistem tradisional (proses turun temurun) dan pegaraman dengan geoisolator (proses dengan terapan teknologi). Proses pembuatan garam dengan sistem tradisional merupakan proses yang di lakukan secara turun temurun dari leluhur. Dalam proses ini sentuhan teknologi untuk proses produksi garam sangat minim, media yang digunakan yaitu tanah untuk membuat petak kristalisasi. Sedangkan proses produksi dengan geosiolator menggunakan plastik yang berbahan linier low density poliyethylene atau lebih di kenal dengan plastik geoisolator untuk petak kristalisasi. Penggunaan geoisolator mulai diperkenalkan oleh Dinas Kelautan dan Perikanan Kabupaten Pati mulai tahun 2014, namun tanggapan kurang positif dilakukan oleh petani garam. Petani garam banyak yang menolak penggunaan geoisolator dikarenakan petani beranggapan penggunaan geoisolator akan mengurangi produktivitas serta mengurangi keuntungan.

Penggunaan tenaga kerja pada usaha pertanian garam tradisional maupun geoisolator tidak jauh berbeda. biaya yang diperlukan pada usaha pertanian garam tradisional sebesar $\mathrm{Rp}$ 16.031.250, sedangkan usaha pertanian garam menggunakan geoisolator membutuhkan biaya tenaga kerja sebesar Rp18.756.250. Penggunaan biaya tenaga kerja dapat ditekan dengan memberdayakan tenaga kerja dari keluarga (istri atau anak) untuk proses pemanenan, sehingga pengeluaran biaya tenaga kerja akan berkurang.

Permodalan usaha pertanian garam berasal dari petani sendiri serta dari pinjaman pihak luar seperti perbankan dan koperasi, serta ada beberapa petani yang memperoleh bantuan permodalan dari pemerintah. Pertanian garam pengguna geoisolator membutuhkan modal yang lebih besar daripada yang menggunakan cara tradisional. Hal tersebut dikarenakan pengadaan plastik berbahan geoisolator yang mahal. Namun modal usaha pertanian garam setiap tahun akan berbeda karena kebutuhan peralatan yang tidak habis pakai dalam satu musim dapat digunakan kembali pada musim penggaraman berikutnya.

Sistem pemasaran hasil pertanian garam dari petani mayoritas dijual langsung kepada tengkulak. Penentuan harga garam melalui mekanisme harga pasar, dan biasanya diklasifikasikan sesuai kualitas yang diniliai dari visual garam. Garam yang lebih putih dan bersih akan dihargai lebih mahal, yaitu garam yang 
dihasilkan dari penggunaan geoisolator. Selisih harga antara garam yang dihasilkan dengan cara tradisional dan penggunaan geoisolator yaitu $\mathrm{Rp}$ 100 per $\mathrm{Kg}$. Sementara sebagian petani lain menjual garam kepada koperasi yang dikelola oleh kelompok usaha pertanian garam yang ditentukan oleh pemerintah. Berjalannya sistem pemasaran garam melalui koperasi baru berjalan pada tahun 2017 karena gudang yang disediakan peerintah baru tersedia di Desa Raci Kecamatan Batangan. Diharapkan adanya gudang tersebut dapat mengontrol harga garam yang sering berfuktuatif.

Keuntungan usaha pertanian garam tradisional dan pengguna geoisolator di kecamatan batangan dan juwana kabupaten pati, penerimaan usaha diperoleh dari hasil penjualan produksi garam. sedangkan keuntungan petani garam diperoleh dari total penerimaan dikurangi dengan total biaya pengeluaran. Harga penjualan yang digunakan berdasarkan dari ketentuan yang telah di tetapkan oleh pedagang atau tengkulak. Harga jual tergantung dari kualitas garam yang dihasilkan. Pembedaan kualitas garam yang di lakukan berdasarkan visual garam karena belum ada aturan yang mengatur tentang kualitas garam yang ada di lapangan.Perbandingan hasil analisis pendapatan dan keuntungan usaha pertanian garam tradisional dan pengguna geoisolator disajikan pada gambar 2

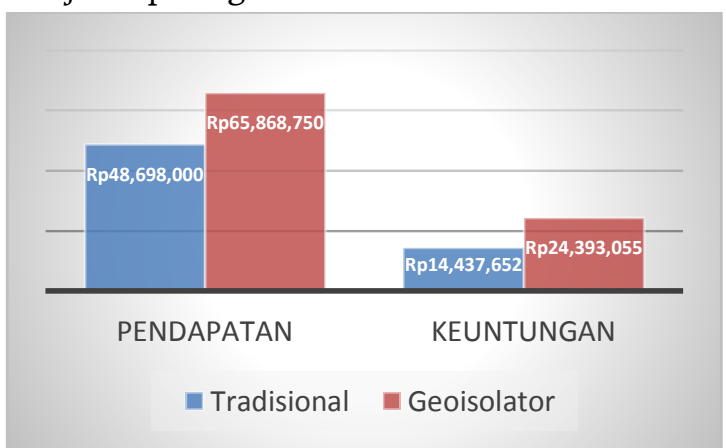

Gambar 2. Hasil Analisis Pendapatan dan Keuntunan

Sumber: Diolah dari data primer 2017

Gambar 2 menunjukkan perbandingan penerimaan serta keuntungan usaha pertanian garam tradisional dan pengguna geoisolator Pendapatan petani garam tradisional lebih kecil daripada pengguna geoisolator dengan selisih Rp18.000.000. Hal tersebut dikarenakan output yang dihasilkan petani garam pengguna geoisolator lebih tinggi dari sisi kuantitas maupun kualitas, sehingga garam yang di hasilkan di hargai lebih mahal. Keuntungan yang di peroleh petani pengguna geoisolator juga lebih tinggi daripada yang tidak menggunakan. Walaupun modal yang diperlukan petani pengguna geoisolator lebih besar namun hal tersebut ternyata tidak mempengaruhi keuntungan yang di terima.

Analisis imbangan penerimaan dan biaya (R/C Ratio) bertujuan untuk mengetahui hasil yang diperoleh dari suatu kegiatan usaha. Jika $\mathrm{R} / \mathrm{C}>1$, maka usaha tersebut mendapat keuntungan, jika $\mathrm{R} / \mathrm{C}<1$, maka usaha tersebut mengalami kerugian, dan jika $\mathrm{R} / \mathrm{C}=1$, maka usaha tersebut berada pada titik impas. Hasil analisis imbangan penerimaan dan biaya (R/C Ratio) kedua kegiatan usaha tani garam samasama menguntungkan. Nilai R/C Ratio usaha pertanian garam tradisional 1,42 berarti setiap petani mengeluarkan biaya sebesar 1 rupiah, maka akan diperoleh penerimaan sebesar 1,42 rupiah. Pada usaha pertanian garam pengguna geoisolator mempunyai nilai R/C Ratio 1.52 sehingga setiap mengeluarkan biaya sebesar 1 rupiah, maka akan diperoleh penerimaan sebesar 1,52 rupiah.

Break Event Point (BEP) digunakan untuk melihat batas minimal produk yang harus diproduksi agar suatu usaha dapat mendapat keuntungan. Usaha dikatakan berada pada titik impas, jika total penerimaan sama dengan total biaya $(\mathrm{TR}=\mathrm{TC})$. Jika total pendapatan berada di atas titik impas, maka usaha berada pada keadaan untung dan demikian sebaliknya, jika total pendapatan yang diperoleh berada di bawah titik impas, maka usaha dalam keadaan rugi. Hasil perhitungan BEP disajikan pada tabel 1

Tabel 1. Nilai BEP Usaha Pertanian Garam Tradisional dan Pengguna Geoisolator

\begin{tabular}{lrr}
\hline BEP & \multicolumn{1}{c}{ Tradisional } & \multicolumn{1}{l}{ Geoisolator } \\
\hline Nilai (Rp) & $26.433 .860,89$ & $28.940 .964,74$ \\
Volume (Kg) & $33.042,33$ & $34.218,51$ \\
\hline
\end{tabular}

Sumber: Diolah dari data Primer 2017

Tabel 1 menunjukkan usaha pertanian garam tradisional maupun pengguna geoisolator sama-sama menguntungkan di tinjau dari BEP 
nilai dan BEP volume. BEP usaha pertanian garam pengguna geoisolator lebih tinggi dikarenakan proses pada produksi usaha membutuhkan biaya yang lebih tinggi dibandingkan tradisional. Sehingga hal tersebut mempengaruhi hasil BEP nilai maupun BEP volume.

Kelayakan finansial usaha pertanian garam di kecamatan batangan dan juwana kabupaten pati, guna mempermudah perhitungan analisis kelayakan finansial suatu usaha, maka perlu disusun perkiraan cash flow. Dalam penyusunan cast flow atau aliran kas diperlukan asumsiasumsi yang mendukung. Asumsi yang digunakan untuk penyusunan cast flow pada usaha tambak garam adalah: Umur proyek ditentukan selama lima tahun, didasarkan pada perkiraan umur teknis kincir, pompa, dan selender yang merupakan komponen investasi terbesar pada usaha pertanian garam, usaha pertanian garam diasumsikan sebagai usaha yang baru dimulai, sumber modal yang digunakan dalam usaha tambak garam berasal dari modal sendiri, harga jual garam merupakan harga jual berlaku di daerah penelitian yang di komparasikan dari tahun 2014 sampai tahun 2015 dan di asumsikan setiap tahunnya sama, produksi garam tradisional yaitu cara usaha tambak garam yang sudah dilakukan turun temurun yang menggunakan media tanah sebagai dasaran meja kristalisasi, produksi garam pengguna geoisolator yaitu cara usaha tambak garam yang baru diperkenalkan kepada petani menggunakan media plastik geoisolator sebagai dasaran meja kristalisasi, discount rate yang digunakan berdasarkan tingkat suku bunga pinjaman Bank Rakyat Indonesia pada tahun 2017 yaitu sebesar $17.5 \%$.

Analisis kriteria investasi usaha pertanian garam dapat dilihat dari dua kriteria, yaitu Net Present Value (NPV) dan Net Benefit-Cost (Net B-C). Ketiga kriteria terebut digunakan untuk mengetahui usaha pertanian garam layak untuk dijalankan atau tidak. Ada pun hasil perhitungan nilai NPV dan Net B-C usaha pertanian garam dapat dilihat pada Tabel 2

Tabel 2. Nilai NPV, Net B/C, dan IRR Usaha Pertanian Garam dengan Luas Lahan 1 Ha di Kecamatan Batangan dan Juwana

\begin{tabular}{ccc}
\hline Kriteria Investasi & Tradisional & Geoisolator \\
\hline NPV (Rp) & $47.853 .908,99$ & $50.897 .649,08$ \\
Net B-C & 16,892 & 4,431 \\
IRR $(\%)$ & 536.0 & 200.3 \\
\hline
\end{tabular}

Sumber: Dioah dari data primer, tahun 2017

Analisis kelayakan usaha pertanian garam tradisional tanpa pinjaman dengan discount rate 17.5\%. Pada produksi garam dengan cara tradisional diperoleh nilai NPV sebesar Rp. 47.853.908,99. Nilai tersebut memberikan pengertian jumlah manfaat bersih yang diperoleh selama umur proyek lima tahun yang dihitung berdasarkan nilai saat ini pada tingkat suku bunga $17.5 \%$ per tahun adalah $\mathrm{Rp}$. 47.853.908,99. Sedangkan nilai Net B/C yang diperoleh sebesar 16,892. Nilai tersebut merupakan perbandingan antara manfaat yang diperoleh selama umur proyek dengan biaya yang dikeluarkan selama umur proyek. Nilai IRR 536.0\% mempunyai arti bahwa usaha pertanian garam memberikan tingkat manfaat bersih internal sebagai akibat dari investasi yang ditanamkan selama umur proyek sebesar 536.0\% per tahun. Hasil perhitungan analisis kelayakan usaha pertanian garam dengan cara tradisional menunjukkan bahwa usaha pertanian garam layak untuk dilanjutkan, karena hasil kriteria investasi yang diperoleh adalah $\mathrm{NPV}>1$, Net $\mathrm{B} / \mathrm{C}>1$, dan IRR $>$ discount rate sehingga memenuhi kriteria yang berlaku.

Usaha pertanian garam dengan geoisolator menunjukkan nilai NPV sebesar Rp 50.897.649,08 yang mempunyai arti bahwa jumlah manfaat bersih yang diperoleh selama umur proyek 5 tahun yang dihitung berdasarkan nilai saat ini pada tingkat suku bunga $17.5 \%$ per tahun adalah $\mathrm{Rp} 50.897 .649,08$. Sedangkan nilai Net B/C yang diperoleh sebesar 4,431. Nilai tersebut merupakan perbandingan antara 
manfaat yang diperoleh selama umur proyek dengan biaya yang dikeluarkan selama umur proyek. Nilai IRR 200.3\% mempunyai arti bahwa usaha pertanian garam memberikan tingkat manfaat bersih internal sebagai akibat dari investasi yang ditanamkan selama umur proyek sebesar 200.3\% per tahun. Hasil perhitungan analisis kelayakan usaha pertanian garam dengan dengan geoisolator menunjukkan bahwa usaha pertanian garam layak untuk dilanjutkan, karena hasil kriteria investasi yang diperoleh adalah NPV $>1$, Net B/C $>1$, dan IRR > discount rate sehingga memenuhi kriteria yang berlaku.

Analisis sensitivitas pada usaha pertanian garam dilakukan untuk melihat sejauh mana kepekaan usaha yang terjadi pada cara tradisional dan menggunakan geoisolator. Pada usaha pertanian garam komponen yang dianggap paling peka dan berpengaruh penting terhadap kelayakan usaha adalah penurunan harga jual, hal tersebut sejalan dengan penelitian yang dilakukan oleh Amaliya (2007) dan Nursaulah (2013). Harga bahan baku tidak mempengaruhi kelayakan usaha ini, karena bahan baku yang berasal dari air laut diperoleh secara gratis, hal inilah yang membedakan usaha pertanian garam berbeda dengan usaha-usaha pertanian lainnya. Hasil dari analisis sensitivitas dapat dilihat pada Tabel 3

Tabel 3. Hasil Perbandingan Nilai NPV, Net B/C, dan IRR Usaha Pertanian Garam dengan Luas Lahan 1 Ha Akibat Penurunan Harga Jual Garam

\begin{tabular}{lrr}
\hline \multicolumn{1}{c}{ Kriteria Investasi } & $\begin{array}{c}\text { Sebelum Penurunan Harga } \\
\text { Jual Garam }\end{array}$ & $\begin{array}{c}\text { Setelah Penurunan Harga } \\
\text { Jual Garam }\end{array}$ \\
\hline & Tradisional (31.2\%) & $(121.882,64)$ \\
NPV (Rp) & $47.853 .908,99$ & 0,959 \\
Net B/C & 16,892 & 16,87 \\
IRR (\%) & 536.0 & \\
& & \\
NPV (Rp) & Geoisolator (24.5\%) & $(145.068,85)$ \\
Net B/C & $50.897 .649,08$ & 0,991 \\
IRR (\%) & 4,430 & 17,18 \\
\hline
\end{tabular}

Sumber: Diolah dari data primer, tahun 2017

Pada Tabel 5 usaha pertanian garam dengan menggunakan geoisolator lebih sensitif dibandingkan dengan usaha pertanian garam tradisional, apabila terjadi penurunan harga sebesar $24,5 \%$. Penurunan harga jual garam tersebut sangat berpengaruh terhadap penerimaan yang akan diterima oleh petani garam.

\section{SIMPULAN}

Simpulan dari penelitian ini adalah mekanisme produksi usaha pertanian garam di Kecamatan Batangan dan Juwana Kabupaten Pati yang pertama menggunakan cara tradisional yang sudah turun temurun dari leluhur petani, yang kedua dengan menggunakan geoisolator yang baru diperkenalkan pada tahun 2014 . Permodalan menggunakan modal sendiri serta bantuan pinjaman dari lembaga keuangan, untuk usaha pertanian garam pengguna geoisolator membutuhkan modal yang lebih besar daripada cara tradisional. Begitu juga dengan kebutuhan biaya tenaga kerja usaha pertanian garam pengguna geoisolator lebih besar daripada cara tradisional. Harga jual garam yang dihasilkan melalui penggunaan geoisolator lebih tinggi $\mathrm{Rp}$. 100 per $\mathrm{Kg}$ daripada garam hasil tradisional. Sedangkan sistem penjualan garam oleh petani kebanyakan langsung dijual kepada tengkulak dengan mengikuti sistem harga pasar.

Keuntungan usaha pertanian garam pengguna geoisolator pada luas lahan satu hektar lebih besar daripada usaha pertanian garam tradisional. Nilai keuntungan usaha pertanian garam pengguna geoisolator sebesar $\mathrm{Rp}$. 22.937.083,33 sementara usaha pertanian garam 
tradisional Rp. 15.371.125,00 per musim. Nilai analisis imbangan penerimaan dan biaya (R/C Ratio) kedua usaha pertanian garam sama-sama menguntungkan dengan nilai 1,41 dan 1,53. Nilai BEP kegiatan usaha pertanian garam tradsional yaitu Rp. 26.647.077,74 atau sebanyak $33.308,85 \mathrm{Kg}$. Dari nilai tersebut dapat dikatakan usaha pertanian garam tradisional dalam keadaan untung, karena penerimaan yang diperoleh masih berada diatas titik impas. Begitu pula dengan kegiatan usaha pertanian garam pengguna geoisolator dengan nilai BEP sebesar Rp. $30.908 .207,00$ atau $36.544,49 \mathrm{Kg}$.

Kelayakan finansial usaha pertanian garam tradisional dan pengguna geoisolator sama-sama layak dan menguntungkan, karena nilai bahwa NPV $>1$, Net B/C $>1$, dan IRR $>$ discount rate. Sedangkan analisis sensitivitas menujukkan apabila terjadi penurunan harga jual garam, usaha pertanian garam tidak layak untuk dijalankan. Usaha pertanian garam pengguna geoisolator lebih sensitif terhadap perubahan harga apabila terjadi penurunan harga sebesar $24.5 \%$, maka usaha pertanian garam jadi tidak layak.

Saran bagi petani garam Kecamatan Batangan dan Juwana untuk menggunakan geoisolator untuk meningkatkan keuntungan. Diharap pemerintah terkait dapat memberikan bantuan kepada petani berupa pendampingan langsung ataupun pemberian bantuan langsung karena usaha pertanian garam menggunakan geoisolator membutuhkan modal yang besar. Karena usaha pertanian garam sangat sensitif terhadap perubahan harga disarankan pemerintah dapat mengatur kestabilan harga jual dari petani garam. Diharapkan petani mempunyai ketertarikan menggunakan geoisolator serta tidak khawatir kerugian usaha karena harga jual garam yang stabil..

\section{DAFTAR PUSTAKA}

Amaliya, Rifqa Wahdini. (2007). Analisis Finansial Usaha Tambak Garam di Desa Pinggirpapas, Kecamatan Kalianget, Kabupaten Sumenep, Provinsi Jawa Tengah. Skiripsi. Bogor: Fakultas Teknologi Pertanian IPB.

Dinas Kelautan dan Perikanan. (2016). Laporan Akhir Pugar 2015. Pati: Pemerintah Kabupaten Pati.
Efendy, M., Heryanto, A., Sidik, R. F., Muhsoni, F. F. (2016). Perencanaan Usaha Korporatisasi Usaha Garam Rakyat. Jakarta: Sekretariat Direktorat Jenderal Pengelolaan Ruang Laut, Kementerian Kelautan dan Perikanan.

Hidayah, Z. (2016). Efektifitas Program Pemberdayaan Usaha Garam Rakyat di Pesisir Selat Madura (Studi Kasus Konversi Lahan Garam Tradisional Menjadi Lahan Garam Geomembran). Jurnal Prosiding Seminar Nasional Kelautan 2016. Hal 209-215 Madura: Universitas Trunojoyo Madura.

Ibrahim, Yocab. (2009).Studi Kelayakan Bisnis. Jakarta: PT Rineka Cipta.

Nursaulah dan sasongko. (2013). Evaluasi Kelayakan Usaha Garam Rakyat Berpola Subsisten Dalam Rangka Pembangunan Ekonomi Di Kawasan Pesisir (Studi Pada Kelompok Petani Garam Pugar Kabupaten Pasuruan). Jurnal Ilmiah. Malang: Jurusan Ilmu Ekonomi, Fakultas Ekonomi, Universitas Brawijaya

Pasaribu, Ali Musa (2012). Perencanaan \& Evaluasi Proyek Agribisnis (konsep \& aplikasi). Yogyakarta: Lili Publisher.

Peraturan Menteri Perdagangan Republik Indonesia Nomor.125/M-DAG/PER/12/2015 tentang Ketentuan Impor Garam. 2015. Jakarta.

Pranowo, S A., \& Muhajir. (2015). Dukungan Klinik Iptek Mina Bisnis (KIMBis) Pada Program Pemberdayaan Usaha Garam Rakyat (PUGAR) di Kabupaten Pati. Buletin Ilmiah "MARINA" Sosial Ekonomi Kelautan dan Perikanan Vol. 1 No. 1. Hal 19-28 Pati: Balai Besar Penelitian Sosial Ekonomi Kelautan dan Perikanan.

Sinaga, Dadjim. (2009). Studi Kelayakan Bisnis dalam Ekonomi Global: teori aplikasinya dalam evaluasi proyek. Jakarta: Mitra Wacana Media.

Soeharjo A. dan Patong D. (1973). Sendi-Sendi Pokok Ilmu Usahatani. Bogor: Jurusan Ilmu-Ilmu Sosial Ekonomi Fakultas Pertanian Institut Pertanian Bogor.

Soekartawi. (2002). Analisis Usahatani. Jakarta: Universitas Indonesia-Press.

Soekartawi, A. Soeharjo, John L. Dillon, J. Brian Hardaker. (1986). Ilmu Usaha Tani dan Penelitian untuk Pengembangan Petani Kecil. Jakarta: Universitas Indonesia-Press. 